MILUTIN ŽIVKOVIĆ, istraživač-saradnik

Institut za srpsku kulturu, Priština - Leposavić

Leposavić, 24. novembra b. b.

mzivkovickv@gmail.com

originalan naučni rad

UDK 94(497.16:450)"1942"(093.2)

primljeno: 23. februar 2016.

prihvaćeno: 20. april 2016.

\title{
USPOSTAVLJANJE SARADNJE KOMANDANTA LIMSKO-SANDŽAČKIH ČETNIČKIH ODREDA PAVLA ĐURIŠIĆA I ITALIJANSKIH VLASTI U CRNOJ GORI POČETKOM 1942.*
}

APSTRAKT: U članku je analizirana serija sastanaka koje je kapetan Pavle Đurišić imao sa oficirima komande italijanske divizije "Venecija" sa sedištem u Beranama. Hronološki su izloženi Đurišićevi pregovori sa predstavnicima okupatorskih vlasti u Crnoj Gori, kao i rezultati do kojih su doveli, od prvih kontakata početkom januara 1942, do potpisivanja ugovora o vojnoj saradnji u Beranama krajem marta iste godine. Rad je pisan na osnovu grade koja se nalazi u Arhivu istorijskog odeljenja Generalštaba Republike Italije i Vojnog arhiva Srbije, kao i na odabranoj naučnoj literaturi.

KLJUČNE REČI: kapetan Pavle Đurišić, sastanak, general Bonini, potpukovnik Simoneli, divizija „Venecija“, Komanda trupa Crne Gore

Krajem 1941. godine rasplamsao se ideološki građanski rat na teritoriji Crne Gore i Starog Rasa. Oficiri Jugoslovenske vojske u otadžbini (JVuO), čija je organizacija na ovom prostoru bila u povoju, nalazili su se pod vojnim pritiskom brojnijih komunista, dok im je revolucionarni teror smanjivao broj raspoloživih ljudi. Opasnost je pretila i od lokalnih muslimanskih odreda, dobro naoružanih od strane režima Nezavisne Države Hrvatske (NDH). Stoga se neki od njih, poput majora Đorđija Lašića ili kapetana Pavla Đurišića, okreću italijanskim okupacionim vlastima radi dobijanja vojne pomoći. Đurišićeva diplomatska inicijativa pri komandi divizije „Venecija“ (Venezia) tokom prvih meseci 1942. poklapa se sa pregovorima

* Rad je deo projekta Materijalna i duhovna kultura Kosova i Metohije (178028) koji finansira Ministarstvo prosvete, nauke i tehnološkog razvoja Republike Srbije. 
četničkih prvaka sa Italijanima na području Dalmacije, Like i zapadne Bosne, pa ima širi istorijski kontekst. Putem pregovora Đurišić je, pre svega, želeo da osigura i ubrza stvaranje svojih jedinica. Postepenim nastupom težio je da neutralizuje Italijane kao mogućeg protivnika, a zatim da ih pretvori u saveznika u sukobu sa komunistima i od njih dobije zaštitu od muslimana. Prihvativši pregovore sa Đurišićem, italijanske vojne vlasti su nastojale da pacifikuju određene zone u okupiranoj Crnoj Gori, povećaju opštu bezbednost, uz što manje trošenje ljudskih i materijalnih resursa, ne ispuštajući pritom iz vida šta je suština pokreta koji se nalazio sa druge strane pregovaračkog stola.

Tokom perioda januar - april 1942. kapetan Pavle Đurišić, komandant Limsko-sandžačkih četničkih odreda, ${ }^{1}$ imao je seriju od osam susreta sa predstavnicima italijanske divizije „Venecija“. Svi su se odigrali u Beranama. ${ }^{2}$ Ona će rezultirati njegovom kolaboracijom sa Italijanima protiv par-

${ }^{1}$ Dragoljub Mihailović je polovinom oktobra 1941. odredio Đurišića za komandanta svih četničkih snaga u Andrijevačkom, Beranskom, Bjelopoljskom, Prijepoljskom, Pljevaljskom i Kolašinskom srezu. Pod njegovu komandu su potpale i jedinice u Barskoj i Buđevskoj opštini Sjeničkog sreza. Vojni arhiv Srbije (VA), Četnička arhiva (ČA), kutija (kut.) 1, fascikla (fasc.) 1, dokument (dok.) 1, strana (str.) 1.

${ }^{2}$ Sedište 19. brdske pešadijske divizije „Venecija“ bilo je u Firenci. Njen sastav činili su: 83. pešadijski puk, 84. pešadijski puk, 19. artiljerijski puk, 19. minobacački bataljon, a 1942. godine pridodat joj je 383. pešadijski puk. Pešadijski pukovi su imali po tri bataljona. Diviziji je 1941. godine potčinjena 72. legija crnokošuljaša sa 63 . i 111. bataljonom. Formirana je aprila 1939, mada njeni začeci sežu sve do 1883. godine, kada je stvorena brigada sa istim imenom. Ona je u svom sastavu imala 83. i 84. pešadijski puk. Godine 1934. brigada je ušla u sastav 19. pešadijske divizije „Gavinana“ (Gavinana). Polovinom aprila 1939, menja ime u 19. pešadijsku diviziju „Venecija“. Njeno ljudstvo je 1935. prebačeno u Eritreju, odakle je 1935-1936. uzelo učešća u okupaciji Etiopije. Tokom ovog rata jedinica je imala zapaženu ulogu. Prilikom zauzimanja Albanije divizija „Venecija“ je osvojila Drač, posle čega je raspoređena na garnizonsku službu u Elbasanu i Pogradecu. Tu je dočekala ulazak Italije u Drugi svetski rat. Krajem oktobra 1940. usled grčko-italijanskog rata prebačena je u zonu Korče gde se sukobila sa grčkom vojskom. Tokom oktobra i novembra 1941. učestvovala je u akcijama kao podrška 3. alpskoj diviziji „Julia“ (Julia). Usled grčke kontraofanzive povučena je na odbrambene pozicije oko Devola i Podgradeca. Posle okupacije Grčke ostala je do jula 1941. u Albaniji, kada je dislocirana u Crnu Goru. Sedište divizije bilo je u Beranama. Početkom 1942. divizija je imala: 393 oficira i 12.635 podoficira i vojnika. Ukupno: 13.028 ljudi. Raspolagala je sa: 11.600 pušaka, 839 pištolja, 276 puškomitraljeza, 83 teška mitraljeza, 126 minobacača kalibra 45 milimetara, 25 minobacača kalibra 81 milimetar, 48 topova raznih kalibara, 39 motora, 16 automobila i 98 kamiona. Očekivano prebacivanje divizije u Grčku tokom maja 1943. nije izvršeno. Posle kapitulacije Italije deo divizije je razoružan od strane Nemaca, a ostatak se borio na strani partizana u okviru divizije „Garibaldi“. Komandanti divizije bili su: general Silvio Bonini/Silvio Bonini (april 1939 - maj 1943) i general Đovani Batista Ogzilia/Giovani Battista Oxilia (maj 1943 - septembar 1943). Salvatore Orlando, Filippo Capellan, Alessandro Gionfrida, Bolletino dell'Archivio dell'Ufficio Storico, anno II, Numero 3-4, (Rome: Uffisio Storico SME, 2001), 243-244; Archivio dell'Ufficio storico dello Stato maggiore dell'Esercito (AUSSME), 19. divisione fanteria 
tizanskih jedinica. U kontaktima sa Italijanima nastupao je samostalno, bez uplitanja generala Mihailovića. Pošto je uspostavio četničku organizaciju u delovima Beranskog sreza do početka januara $1942,{ }^{3}$ razgovori su otpočeli na Đurišićevo insistiranje. Početkom januara on se obratio komandantu divizije „Venecija“ generalu Silviju Boniniju (Silvio Bonini), zatraživši sastanak. Bonini je prihvatio ponudu i na razgovor poslao načelnika svog štaba potpukovnika Amadea Simonelija (Amadeo Simonelli). ${ }^{4} \mathrm{Za}$ termin prvog sastanka određen je 3. januar 1942. u Beranama.

Đurišić je otvorio razgovore pričom o komunistima. Naveo je da u Beranskom srezu imaju 400, u Andrijevačkom 200 boraca, mnogo više u Kolašinskom i Pljevaljskom, odnosno nešto manje u Bjelopoljskom i Mileševskom srezu. U okolini Nove Varoši su se prema njegovim informacijama nalazile brojne trupe koje su vodili "Tito, Hrvat" i Moša Pijade. Dodao je da je više puta bio pozivan da im se pridruži, ali pošto navodno komunisti nisu želeli da obustave borbu protiv italijanskih trupa, objavio im je „rat do poslednjeg čoveka“. Imajući u vidu jačinu komunista Đurišić je skeptično govorio o formaciji antikomunističke milicije, koju su Italijani formirali na teritoriji Guvernatorata Crne Gore. Smatrao je da ona neće imati uspeha u Beranskom srezu iz više razloga: veći deo ljudstva se već uključio u njegov odred, narod je odlučan da se komunisti suzbiju bez pomoći okupatora i problem milicajaca je $u$ tome što svi, od redova do oficira, imaju rođake među partizanima. ${ }^{5}$ Umesto njih Đurišić je ponudio svoje trupe - 600 boraca dokazanih u sukobima sa komunističkim snagama. Ipak, on nije želeo da saradnja sa italijanskim vlastima bude javna, kako komunistima ne bi pružio jak argument da ga dodatno oslabe. Stoga je više puta naglasio da bi eventualni sporazum morao „biti tajna za sve“. Imao je još nekoliko zahteva: samostalno i nekontrolisano vojno delovanje, sloboda političke akcije i

„Venezia“, bus(ta) N-6/1006, Comando della divisione di fanteria da montagna „Venezia“, Stato Maggiore, Effetivi della divisione fanteria da montagna „Venezia“, alla data del 1. gennaio 1942 (elementi organici), 1.

3 Đurišić je početkom januara sazvao zbor oficira bivše kraljevske vojske u selu Zaostro kod Berana. Tamo je od strane nekoliko po činu viših oficira priznat za zapovednika. U narednim danima sproveo je četničku organizaciju na teritoriji Beranskog sreza. Zatim mu prilazi celokupna sreska antikomunistička milicija sa 500 ljudi, kao i komandanti Ljubo Minić iz Kolašinskog sreza i Radojica Orović sa oko 120 boraca. U okviru odreda osnovao je Politički komitet koji je širio četničku propagandu i u koji su ušli viđeniji lokalni intelektualci. VA, ČA, kut. 139, fasc. 1, dok. 12, 1-2; Glas Crnogoraca, br. 13, 18. 4. 1942, 2; Радоје

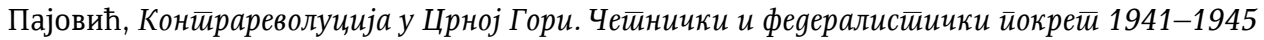
(Цетиње: Историјски институт Социјалистичке републике Црне Горе, 1977), 169-170.

${ }^{4}$ AUSSME, 19. divisione fanteria „Venezia“, bus. N-6/1006, Comando della divisione di fanteria da montagna „Venezia“, Capitano Pavle Giurisic, Nr. 179, 11. 1. 1942, 1.

${ }^{5}$ AUSSME, 19. divisione fanteria „Venezia“, bus. N-6/1006, Comando della divisione di fanteria da montagna „Venezia“, Capitano Pavle Giurisic, Nr. 307, 16. 1. 1942, 1; P. Пајовић, н. g., 118. 
propagande, širenje operacija protiv komunista na Andrijevački, Beranski, Bjelopoljski, Kolašinski, Pljevaljski i Prijepoljski srez i isporuka veće količine oružja, tačnije 3.000 pušaka, 110 automatskih oružja, 40 lakih i teških minobacača i 1-2 topa. Oružje po Đurišiću nije trebalo da bude italijanske proizvodnje, opet da narod ne bi posumnjao u saradnju sa okupatorom. Kao zalog svoje odanosti, ponudio je za taoce majku, ženu i sina. Poručio je i da će doći kod generala Boninija kada god da ga pozove, bez ikakvih garancija bezbednosti. ${ }^{6}$

U drugom delu sastanka od Đurišića se tražilo da iznese karakteristike nekih ličnosti za koje su italijanske vlasti bile zainteresovane. U pitanju su bili: Milan Bandović, predsednik opštine Zaton, major Miomir Cemović, advokat Filip Cemović, major Radoslav Joksimović, Reka Šahman (koga je Đurišić nazvao razbojnikom), Jusuf Ćorović i hodža Osman Rastoder. Đurišić je pravoslavce uglavnom hvalio, ali je navodio i ko od njih ima nekoga među partizanima. Četnički komandant je pohvalio i vodeće muslimanske prvake iz tih krajeva Jusufa Ćorovića, predsednika opštine Lozna i Osmana Rastodera, hodžu iz Petnice, koje je predstavio „kao dobre i odane osobe od poverenja“. ${ }^{7}$ Dalje je potpukovnika Simonelija zamolio da se planirana italijanska evakuacija Kolašina odloži dok njegove snage ne ojačaju. Za komuniste bi, po njegovoj oceni, bila velika prednost ako bi zaposeli varoš. Srpski oficir je zaključio razgovor naglasivši više puta „simpatiju i naklonost koje oseća prema Italijanima zbog njihove odanosti, dobrote, ponekad i preterane". $\mathrm{Na}$ kraju izveštaja za generala Boninija, u mnogo čemu afirmativnog za Đurišića, potpukovnik Simoneli piše da se zahtevima četničkog komandanta "može udovoljiti, kako bi se otvoreno pokazalo da italijanske vlasti veruju u njegov antikomunistički pokret $i$ uzdaju se u reč jednog vojnika koji tvrdi da je zarad antikomunističkog ideala spreman da položi život", kao i da "u Đurišiće$v u$ lojalnost ne treba sumnjati, zbog spontane i ponovljene ponude da članove svoje porodice dâ kao taoce". Reči italijanskog oficira odslikavaju pozitivan utisak koji je kapetan Đurišić ostavio prilikom prvog susreta, na kojem su udareni temelji buduće saradnje između njega i italijanskih vojnih vlasti u Crnoj Gori. ${ }^{8}$

Proučivši dopis svog oficira komandant divizije „Venecija“ general Bonini je 11. januara o tome obavestio Komandu trupa Crne Gore (Comando Truppe Montenegro). Iako nije prisustvovao sastanku, njegovo tumačenje bilo je pronicljivije nego ono koje je dao Đurišićev sagovornik. Bonini je naveo da Đurišića treba upotrebiti, jer je neosporni nacionalista sa iskustvom

${ }^{6}$ AUSSME, 19. divisione fanteria „Venezia“, bus. N-6/1006, Comando della divisione di fanteria da montagna „Venezia“, Capitano Pavle Giurisic, Nr. 307, 16. 1. 1942, 2.

${ }^{7}$ Ibid., 2-3.

${ }^{8}$ Ibid., 3-4. 
borbe protiv komunista. Savetovao je, ipak, opreznost zbog njegovih veza sa generalom Mihailovićem i dodao da eventualna saradnja treba da bude potpuno pod "kontrolom italijanskih vlasti“. U tome je italijanski oficir video srž problema: „Đurišić želi nezavisnost kako bi naknadno pretvorio antikomunistički pokret u jugoslovenski pokret, tačnije antiitalijanski. Tražena saradnja sa Italijanima je sredstvo kojim će se služiti u prvo vreme da bi porazio komunizam. Kasnije će borba biti okrenuta protiv nas da bi se ponovo rodila velika Jugoslavija... Garancije koje Đurišić želi da dâ kao dokaz odanosti prema nama odnose se prema mom mišljenju samo na njegovu aktivnost u prvo vreme". Italijanski general je zbog toga smatrao za "nelogičnu meru“ davanje oružja četničkom komandantu. Boninijeve ocene pokazuju stepen međusobnog poverenja među budućim saveznicima i predstavljaju konstantu koja će opterećivati četničko-italijansku saradnju. ${ }^{9}$

Negativnu sliku o Đurišićevim predlozima Bonini je zaokružio mišljenjem da su njegove simpatije prema Italijanima neiskrene i da im se sada približava u strahu od borbe na dva fronta. Ipak, kao realan političar, zaključio je da treba "održavati kontakte sa Đurišićem i u mogućim granicama pratiti njegov rad", jer to Italijanima garantuje "određenu slobodu za akcije saobraćajnicama i sigurnost da mostovi na nekim putevima neće biti rušeni". Stoga je preporučio Komandi trupa Crne Gore da isporuči Đurišiću izvesnu količinu oružja i započne saradnju manjeg intenziteta sa četnicima na teritoriji divizije „Venecija“. ${ }^{10}$

Nadležni vojni, ali i politički organi prihvatili su Boninijeve sugestije. Naime, uz kontakte italijanskih vlasti u Crnoj Gori sa kapetanom Đurišićem, odnosno pukovnikom Stanišićem, uspostavljana je italijanskočetnička saradnja i u drugim krajevima okupirane Jugoslavije. Tako je komanda 2. italijanske armije ponovo otvorila pregovore sa vojvodom Ilijom Trifunovićem Birčaninom i Dobrosavom Jevđevićem u Splitu. I ovde su impuls saradnji davali četnički prvaci i lokalni italijanski generali, poput komandanta 2. armije Marija Roate (Mario Roatta). Njegov cilj je bio da pacifikuje četnike i okrene ih protiv komunista na prostoru Like, Dalmacije i zapadne Bosne, odnosno da uz pomoć njih destabilizuje ustaški režim u NDH. Ovi pregovori će rezultirati stvaranjem Dinarske četničke divizije. ${ }^{11}$ Namere predstavnika italijanskih vojnih vlasti u Crnoj Gori, od generala Pircija Birolija (Pirzio Biroli), preko generala Luiđija Mentastija (Luigi Mentasti), komandanta italijanskih trupa u Crnoj Gori, do generala Bonini-

${ }^{9}$ AUSSME, 19. divisionefanteria „Venezia“, bus. N-6/1006, Comando della divisione di fanteria da montagna „Venezia“, Capitano Pavle Giurisic, Nr. 179, 11. 1. 1942, 1-2.

${ }^{10}$ Ibid., 2.

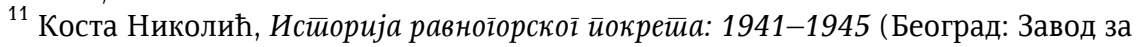
уџбенике, 2014), 250-251. 
ja, nisu se u mnogome razlikovale od planova generala Roate. ${ }^{12}$ Bile su, ipak, u suprotnosti sa politikom italijanske vlade koja nije blagonaklono gledala na saradnju sa četnicima. Latentna podrška po ovom pitanju dobijena je od najviših vojnih krugova u Italiji, odnosno generala Vitorija Ambrozija (Vittorio Ambrosio), načelnika Vrhovne komande italijanskih trupa. ${ }^{13}$ Ne treba ispustiti iz vida i da je vojvoda Birčanin, odlikovani borac iz prethodnih ratova, saradnik britanske obaveštajne službe i jedan od stubova saradnje sa Italijanima, od okupacije do oktobra 1941. živeo ilegalno u Kolašinu, pre nego što je otišao za Split. ${ }^{14}$

U iščekivanju odgovora italijanskih vlasti, Đurišić je nastavio diplomatsku akciju. Dana 13. januara u 22 časa imao je novi susret sa predstavnicima divizije „Venecija“. Do sastanka je došlo jer je oficir JVuO saznao da Italijani primaju vesti sa više strana o njegovom antiitalijanskom stavu i saradnji sa generalom Mihailovićem, koje su pretile da ugroze nastavak pregovora. Odmah na početku on je odbacio sve glasine, označivši ih kao propagandu komunista. Garantovao je da će ih poraziti i za mesec dana očistiti prostor Sandžaka od njihovih odreda, ako mu se odobre potraživanja u oružju. ${ }^{15}$

Potpukovnik Simoneli se prevashodno interesovao za pitanje odnosa pravoslavnog i muslimanskog stanovništva u kontekstu ideološkog građanskog rata. Na predlog italijanske strane da se $u$ Đurišićevu antikomunističku akciju uključe i muslimanske snage, pre svega iz Petnjice i Bjelopoljskog sreza, načelno je dobijen pozitivan odgovor. Đurišić je tražio da mu kao zalog buduće saradnje muslimanski komandanti omoguće slobodnu akciju na njihovoj teritoriji, materijalno pomognu i obustave napade na pravoslavno stanovništvo. Smatrao je da će ubuduće biti prostora da se razgovor na ovu temu nastavi. ${ }^{16}$ Ipak, pokazao je i određene rezerve prema ovoj inicijativi. Muslimani „neće imati obzira“ ni prema njemu ni prema Italijanima, te će ih u za njih pogodnom trenutku „izdati“, ocenio je Đurišić. ${ }^{17}$ Optužbe je pravdao time da su, prema njegovim informacijama, muslimani iz Bjelopoljskog sreza obezbedili 350.000 dinara i 10 tona žita za pomoć komunistima u toku zime. Komunisti su, s druge strane, koristili muslimane bliske

${ }^{12}$ Dragan S. Nenezić, Jugoslovenske oblasti pod Italijom 1941-1943 (Beograd: Vojno-istorijski institut Vojske Jugoslavije, 1999), 98.

${ }^{13}$ Džejms H. Bergvin, Imperija na Jadranu. Musolinijevo osvajanje Jugoslavije 19411943 (Beograd: Službeni glasnik, 2007), 126-127.

${ }^{14}$ К. Николић, н. g., 249.

${ }^{15}$ AUSSME, 19. divisione fanteria „Venezia“, bus. N-6/1006, Comando della divisione di fanteria da montagna „Venezia“, $2^{\circ}$ incontro con Pavle Giurisic, allegato Nr. 46 al diaro storico, 13. 1. 1942, 1.

${ }^{16}$ Ibid., 1-2.

17 Ibid. 
Partiji, za rad na otvaranju verskog sukoba između muslimana i pravoslavaca, da bi se njegove jedinice tukle na dve strane, dok su još malobrojne. ${ }^{18}$

Da bi kod okupatorskih vlasti oslabio svoje protivnike, Đurišić je došao u pratnji nekoliko poverljivih ljudi, koje je želeo da Italijanima predstavi kao pouzdane izvore informacija i moguće saradnike. Među njima je bio i četnički komandant Milan Bandović, predsednik opštine Zaton. Đurišić ga je preporučio za saradnju, pogotovo kada su u pitanju odnosi sa muslimanima. Ocenio ga je kao vrlo korisnog zato što deluje sa „druge strane Lima (Zaton), gde jedino on sme da ide i odlazi po svojoj volji“. Izrazio je i poverenje u majora Cemovića, bez obzira što je imao rodbinu među partizanima. ${ }^{19}$

Posle toga Đurišić je zatražio od pratilaca da napuste prostoriju. Ostavši sam sa italijanskim oficirima predao im je spisak "osoba iz Berana" koje bi trebalo „ukloniti“. U belešci sa sastanka stoji da je Đurišić imao informacije da ova lica „među sobom drže tajne sastanke i u direktnom kontaktu sa komunistima kuju zaveru za unutrašnju pobunu". Njemu se činilo da spremaju atentate na italijanske oficire, bez izuzetka i na generala. ${ }^{20}$ Razgovor je dalje tekao u pravcu koji je najviše interesovao italijansku stranu, a to je kretanje i jačina komunističkih snaga na teritoriji pod kontrolom divizije. Kao centre njihove akcije u Beranskom srezu Đurišić je označio Lubnice i Kurikuće, gde je bilo nekoliko stotina partizana. On je upozoravao i na mogući napad na Bijelo Polje, koji će izvesti oko 2.000 boraca. Borbu Italijana protiv partizana upotrebom avijacije ocenio je neefikasnom, jer gerilci beže čim čuju zvuk aviona. Pošto italijanski piloti nisu vični letenju na malim visinama, bombe samo razaraju civilne objekte. Stoga je savetovao da se nisko leti jer partizani nemaju protivvazdušnu odbranu, ili da se obustave napadi iz vazduha. ${ }^{21}$

Susret je završen Simonelijevim pitanjem o vezama Đurišića i Mihailovića. On se branio da nema kontakata sa komandantom JVuO, jer ovaj navodno ne komanduje nacionalističkim trupama u Crnoj Gori. Prema Đurišiću o budućnosti Crne Gore će se odlučivati drugom prilikom, dok je sada jedini cilj čišćenje komunista. Zato mu je hitno bilo potrebno oružje. Upozorio je italijansku stranu na posledice neuspostavljanja saradnje sa njegovim četnicima, rekavši: „Ovaj narod želi da se bori i da položi sopstveni život radi jednog jedinog cilja: za jedan nacionalni ideal, u borbi protiv komunizma. Ali ako bi jednog dana ovaj narod razočaran morao da spusti svoje oružje, sigurno je da će krenuti protiv mene i protiv vas". ${ }^{22}$

\footnotetext{
${ }^{18}$ Ibid., 2-3.

${ }^{19}$ Ibid.

${ }^{20}$ Ibid., 3.

${ }^{21}$ Ibid., 4.

${ }^{22}$ Ibid., 4-5.
} 
Šest dana kasnije četnički komandant se ponovo sastao sa Italijanima. Tada je dopunio spisak od 13. januara sa još nekoliko lica koji treba da budu zatvoreni. Đurišić je garantovao da će posle njihovog uklanjanja zona Berana biti očišćena od "osoba koje nisu od poverenja“. Čestitao je italijanskoj strani uspešnu akciju protiv partizana u Ržanici 18. januara, ${ }^{23}$ te predložio da svi zarobljenici, osim dvojice, budu streljani, jer narod takav čin smatra pravednim. Tražio je da italijanska avijacija u niskim naletima bombarduje partizanske položaje u zoni Kurikuća i Lubnice. Posle napada komunisti bi kao i obično napustili naselje, što bi omogućilo njegovim ljudima da uđu u oba mesta. Izrazio je zabrinutost zbog dolaska 400-500 partizana u Ravnu Rijeku, jugozapadno od Bijelog Polja. Smatrao je neophodnim da Italijani sprovedu čišćenje terena ili čak bombardovanje iz vazduha. Izlaganje o komunistima Đurišić je zaključio žalbom da ga oni potiskuju, ne bi li privoleo Italijane da mu isporuče oružje koje je tražio prilikom prvog susreta. Zamolio je Simonelija i da, dok mu Komanda trupa Crne Gore ne odobri zahtev, izdejstvuje još vojne opreme kod generala Boninija. ${ }^{24}$

U toku sastanka pomenuti su ponovo odnosi između pravoslavaca i muslimana. Đurišić je upozorio da muslimani iz Bihora nameravaju da napadnu pravoslavno selo Zaton, iako u njemu ne postoji nijedan komunista, već samo njegovi ljudi. Stoga je zamolio italijansku stranu "da ne veruje hodži Osmanu Rastoderu i Jusufu Ćoroviću da ne bi preduzeli inicijativu i napravili neku štetu u zoni gde su brojni nacionalisti “. ${ }^{25}$ Iako su ove optužbe bile suprotne informacijama koje je o dvojici muslimanskih prvaka Đurišić izneo 3. januara, pokazale su se istinitim. Početkom februara 1942, dok su Đurišićeve trupe vodile borbe sa partizanima u zapadnim delovima Bjelopoljskog sreza, muslimanske snage su upale u Zatonsku opštinu, opkolile selo, a obližnja naselja Ivanje, Raduliće, Potoci, Crnča i Dubovo spalili. ${ }^{26}$

${ }^{23}$ Italijansku vojsku vodio je potpukovnik Frederiko Ćeretani. Tokom akcije u selu Donjoj Ržanici popaljene su kuće plemena Komatine i pri tom ubijene 2 osobe, dok su druge 2 ranjene, a oko 10 lica uhapšeno i kasnije internirano. Arhiv Jugoslavije (AJ), fond 110, Državna komisija za utvrđivanje zločina okupatora i njihovih pomagača (DKRZ), kut. 256, 1031; AJ, fond 110, DKRZ, kut. 102, 212-216.

${ }_{24}$ AUSSME, 19. divisione fanteria „Venezia“, bus. N-6/1006, Comando della divisione di fanteria da montagna „Venezia“, Capitano Pavle Giurisic, Nr. 424, 21. 1. 1942, 1-2.

${ }^{25}$ Ibid.

${ }^{26}$ Viđeniji građani Berana tražili su predstavkom 10. februara 1942. od generala Boninija da njegove trupe spreče dalja nasilja muslimana nad pravoslavcima. Komanda divizije „Venecija“ je naredila muslimanskim prvacima da prekinu napade do 14. februara u 8.00, ili će ona izdati blanko naređenje kapetanu Đurišiću da „izvrši obračun sa muslimanima“. Iako je Đurišić već počeo da priprema akciju odmazde, muslimani su se do 21. februara povukli iz Zatona. Zatim su se pravoslavni i muslimanski politički predstavnici pod pokroviteljstvom Italijana sastali u Bijelom Polju i sporazumeli da prekinu dalje sukobe. VA, ČA, kut. 148, fasc. 4, dok. 7, 1-2; VA, ČA, kut. 132, fasc. 1, dok. 7, 1; VA, ČA, kut. 144, fasc. 4, dok. 6, 1. 
Zanimljivo je istaći da je tokom januara i hodža Osman Rastoder ${ }^{27}$ pokušao da uspostavi direktan kontakt sa komandom divizije „Venecija“, ali je general Bonini to odbio. ${ }^{28}$

U svetlu približavanja četnika i italijanskih vlasti, Boninijev izveštaj generalu Mentastiju bio je ovoga puta naklonjeniji Đurišiću. U dokumentu od 21. januara italijanski visoki oficir pisao je nadležnima o Đurišićevoj pouzdanosti kada je u pitanju dostava informacija (što se verovatno odnosilo na pomenute spiskove), odnosno u ratu protiv komunista. General je, čak, zapisao kako je „impresioniran“ borbom koju je Đurišić vodio. U znak dobre volje, poslao mu je izvesnu količinu zaplenjenih jugoslovenskih bombi. ${ }^{29}$ Tako je Đurišiću pružena podrška za nastavak i produbljivanje saradnje sa italijanskim vlastima, ali je konkretan dogovor još bio daleko.

Zbog ofanzive koju su četnici iz Vasojevića preduzeli u Beranskom i Bjelopoljskom srezu, do narednog sastanka prošlo je skoro mesec dana. Novi razgovori su, opet na Đurišićevu inicijativu, zakazani za 12. februar. $\mathrm{Na}$ početku on se zahvalio italijanskoj strani na pomoći $u$ vidu jedinica antikomunističke milicije iz Andrijevačkog sreza, čijom je borbenošću bio

${ }^{27}$ Osman Rastoder (Radmance, Berane 1882 - Petnjica, Berane 23. januar 1946). Zahvaljujući tome što je bio iz ugledne porodice, mogao je da se školuje. Medresu je pohađao u Đakovici i Novom Pazaru, posle čega odlazi na usavršavanje u Istanbul. Njegova porodica se 1915. seli u Tursku. Po završetku Prvog svetskog rata Rastoder se vraća u rodni kraj, dok ostatak porodice ostaje u emigraciji. Naseljava se u Novom Pazaru, gde se ženi po drugi put. Iz dva braka imao je sedmoro dece. Godine 1926. vraća se u Petnjicu i dobija nameštenje mule (veroučitelja) u selima Petnjici i Savinom Boru. Od 1929. radi i kao imam matičar. Pored srpskog govorio je turski, arapski i albanski jezik. Važio je za jednog od najuglednijih ljudi u Gornjem Bihoru, a kasnije i na celom prostoru Sandžaka. Juna 1941. postavljen je za komandanta lokalnog muslimanskog odreda, koji će u septembru iste godine prerasti u jedinicu muslimanske milicije za Gornji Bihor, koja je sarađivala sa italijanskim okupacionim vlastima. Za vreme Julskog ustanaka napao je sa svojim ljudima prostor Police kod Berana i popalio imovinu pravoslavaca u selima Goražde, Zagrađe, Tmušiće i Lješnici. Zalagao se za pripajanje ovog prostora Velikoj Albaniji i tim povodom išao nekoliko puta u Peć i Tiranu. Bio je, sa druge strane, pristalica oružanog sukoba sa pravoslavcima, pre svih sa onima iz Bjelopoljskog i Beranskog sreza. Na teritoriji Petnjice ostao je do kapitulacije Italije, kada se zbog dolaska partizanskih jedinica prebacuje u Rožaje. Posle oslobođenja beži na Kosovo, ali ne odlazi u emigraciju. Novembra 1945. vraća se u rodni kraj. Neko vreme se krije kod rođaka i drugih muslimana Petnjičke opštine, ali mu organi Uprave državne bezbednosti (UDB) ubrzo ulaze u trag. Milicija ga je ubila 26. januara 1946. na planini Ladevac.

${ }^{28}$ Rastoder je preko svog sina Abdulaha, koji je kasnije tokom 1942. ubijen u Beranama, napisao polovinom januara pismo generalu Boniniju, na temu taktičkih stvari vezanih za njegov odred muslimanske milicije. Iako mu je odgovorio, Bonini mu je naredio da se ubuduće obraća nadređenom mu pukovniku Rosiju (Rossi). AUSSME, 19. divisione fanteria „Venezia“, bus. N-6/1006, Dal Comando divisione Venezia al colonnelo italo Rossi (c. te Trincerato di Berane), Banda di Petnica, Nr. 360, 17. 1. 1942, p. 1; Zumber Muratović, Sandžački gazija Osman Rastoder (Sarajevo: Zumber Muratović, 2002), 29.

${ }^{29}$ AUSSME, 19. divisione fanteria „Venezia“, bus. N-6/1006, Dal Comando divisione Venezia al Comando Truppe Montenegro, Capitano Pavle Giurisic, Nr. 424, 21. 1. 1942, 1. 
zadovoljan. Žalio se, međutim, što njeni komandanti dr Arsović i major Lašić nisu hteli da prihvate njegovu komandu, već su čekali naređenja od divizije „Venecija“, što je uostalom i predviđala odredba o osnivanju milicije. Stoga je molio da se ubuduće stvori jedinstvena komanda. Upitan za mišljenje o verskim sukobima u opštini Zaton, Đurišić je odgovorio da će se borba između muslimana i četnika verovatno nastaviti. Dodao je i da su ga muslimanski prvaci „odbili“ kada je pokušao da utanači sporazum sa njima. Svaki ugovor, uključujući i onaj postignut u Bijelom Polju, označio je relativnim, jer muslimanske vođe iz varoši imaju malo uticaja na istovernike $u$ unutrašnjosti. Takođe, komandanta antikomunističke milicije u Bijelom Polju kapetana Anđelića, koji je stajao iza sporazuma sa muslimanima, označio je za "nesigurni element" ${ }^{30}$

Nastavak sastanka je tekao u manje prijatnoj atmosferi, jer su Italijani ponovo tražili informacije o Đurišićevom stavu prema generalu Mihailoviću. Iako mu je poručeno da general Bonini ceni njegov doprinos antikomunističkoj borbi, Đurišić je morao da se brani od optužbi koje je upravo on izneo na njegov račun posle razgovora 3. januara. Pritisak Italijana je verovatno podstakao i izveštaj majora Đuzepea Picija (Giuzepe Pizzi), v. d. komandanta italijanskog garnizona u Bijelom Polju, od 7. februara u kome je srpski oficir pomenut $u$ vrlo negativnom svetlu. ${ }^{31}$

Đurišić je kategorički odbacio sve optužbe. Zatim je pokušao da ubedi suprotnu stranu da se on bori samo protiv komunista, a ne za Veliku Srbiju ili novu Jugoslaviju, da ne može biti srbofil ili jugoslovenofil s obzirom na to da je tokom vojne karijere uvek „nailazio na prepreke od Srba zato što je Crnogorac", da Kraljevina Jugoslavija nije donela ništa dobro Crnoj Gori, već samo komunizam i slično. Odbacio je optužbe da se sreo sa generalom Mihailovićem, objasnivši da je na granici sa Srbijom bio samo krajem aprila 1941. Tamo je, navodno, našao staru radio-stanicu koju je posle pokazivao kao garant svog sastanka sa Mihailovićem, a sve u cilju dodvoravanja prosrpskoj strani u narodu. Više puta je negirao da se ikada video ili da održava odnose sa zapovednikom JVuO. Na kraju, da bi njegova odbrana

${ }^{30}$ AUSSME, 19. divisione fanteria „Venezia“, bus. N-6/1006, Comando della divisione di fanteria da montagna „Venezia“, $4^{0}$ incontro con capitano Giurisic, Allegato nr. 26, 12. 2. $1942,1$.

${ }^{31}$ Major Pici je izvestio da je preko doušnika dobio informacije kako je Đurišić početkom januara imao duži sastanak sa Mihailovićem. Pici se dalje žalio na njegovu „umerenu aktivnost" u saradnji sa italijanskom vojskom u borbi protiv komunista. Dodao je da Đurišić i njegovi oficiri pokušavaju na sve načine da uguše lojalan stav stanovništva prema okupatoru, tako što stalno pominju gubitak Kosova i podstiču narod da se obračuna sa komunistima, ne bi li se što pre obnovila stara država. AUSSME, 19. divisione fanteria „Venezia“, bus. N-5/811, Comando presidio milittare di Bijelo Polje, Informazioni, Nr. 405, 7. 2. $1942,1$. 
delovala ubedljivije, Italijanima je preneo da „Crna Gora sama ne može da živi i da bi trebalo da postoji u okviru Italije ili Albanije, nikada kao deo Srbije ili velike Jugoslavije koju Crna Gora ne želi“. ${ }^{32}$

General Bonini je, kao i ranije, prosledio nadležnima svoje utiske o susretu Simoneli-Đurišić. Iako je Đurišića optužio za saradnju sa ilegalnim četnicima, ${ }^{33}$ videvši u njegovom delovanju više koristi no štete, Bonini mu je ponovo pred generalom Mentastijem pružio značajnu podršku. U svom izveštaju on je zapisao: „Dok je pri prvom susretu izgledalo sa sigurnošću da je njegovo političko zalaganje bilo usmereno ka ponovnom uspostavljanju velike Jugoslavije, danas je on izričito prestao da bude srbofil ili jugoslovenofil, već stremi isključivo nezavisnoj Crnoj Gori koja bi trebalo da živi u sferi interesa ili Albanije ili Italije“. ${ }^{34}$ Bez skepse je nadležnima preneo i Đurišićev demanti o saradnji sa zapovednikom JVuO, iako po sopstvenom priznanju u njega nije bio siguran. Zaključio je izveštaj afirmišući Đurišića ocenom da „ima kvalitete da postane ključna ličnost" u tom delu Crne Gore. ${ }^{35}$ Da ove preporuke nisu bile samo „mrtvo slovo“ na papiru govore isporuke veće količine jugoslovenske municije Đurišićevim snagama od strane divizije „Venecija“, 22. februara i 10. marta. $^{36}$

Pozitivan stav generala Boninija i uspesi četnika u borbi sa komunističkim snagama oko Kolašina i Bijelog Polja uverili su vrh okupacione uprave u Crnoj Gori da je došlo vreme da se konkretizuju kontakti sa Đurišićem. Na ovu odluku je nesumnjivo uticalo i zaključenje saradnje između pukovnika Stanišića i komandanta 48. fanterijske divizije „Taro" (Taro) generala Pedracolija (Pedrazzoli), od 17. februara 1942. ${ }^{37}$ U pozadini sporazuma o vojnoj saradnji između generala Birolija i pukovnika Baja Stanišića, odnosno vođe federalista u Crnoj Gori generala Krste Popovića, postignutih

32 AUSSME, 19. divisione fanteria „Venezia“, bus. N-6/1006, Comando della divisione di fanteria da montagna „Venezia“, $4^{0}$ incontro con capitano Giurisic, Allegato nr. 26, 12. 2. 1942, 1-2.

${ }^{33}$ Kako se vidi iz italijanske dokumentacije, informacije o navodnom susretu Đurišića i Mihailovića Italijanima preneli su Đurišićev zet Milo Bakić, koji je važio za doušnika Komande trupa Crne Gore i bio član Političkog komiteta pri Limsko-sandžačkom četničkom odredu, i profesor Milutin Jelić. AUSSME, 19. divisione fanteria „Venezia“, bus. N-6/1006, Comando della divisione di fanteria da montagna „Venezia“, Ex capitano dell'esercito yugoslavo Pavle Giurisic, Nr. 722, 17. 2. 1942, 1-2.

${ }^{34}$ AUSSME, 19. divisione fanteria „Venezia“, bus. N-6/1006, Comando della divisione di fanteria da montagna „Venezia“, $4^{0}$ incontro con capitano Giurisic, Allegato nr. 26, 12. 2. 1942, 1-2.

${ }^{35}$ AUSSME, 19. divisione fanteria „Venezia“, bus. N-6/1006, Comando della divisione di fanteria da montagna „Venezia“, Ex capitano dell'esercito yugoslavo Pavle Giurisic, Nr. 722, 17. 2. 1942, 2.

${ }^{36}$ AUSSME, 19. divisione fanteria „Venezia“, bus. N-6/1006, Diretto al Comando Truppe Montenegro, Nr. 337, 22. 2. 1942, 1.

${ }^{37}$ D. S. Nenezić, $n$. d., 97. 
6. marta, ${ }^{38}$ uočava se inicijativa guvernera Crne Gore da istu kolaboracionu matricu proširi i na Đurišićeve četnike. Naime, na početku nove runde razgovora kapetana Đurišića i pukovnika Simonelija, održane istog dana u Beranama, četnički komandant je obavešten da je guverner Biroli poslao dvojicu emisara radi direktnog viđenja sa njim. Sastanak sa Birolijevim deputatima Đurišić je imao 7. marta u okolini varoši. Tom prilikom oni su, između ostalog, podržali četničke zahteve u oružju, čime je praktično dato zeleno svetlo širem ugovoru o vojno-političkoj saradnji. ${ }^{39}$

Prvi martovski susret sa predstavnicima divizije „Venecija“ Đurišić je otvorio izlaganjem plana daljih akcija protiv komunista, nameravajući da se probije u Bratonožiće i Kuče, suzbije njihovu bazu u Piperima i oslobodi put ka Podgorici. Ukazao je takođe na teško materijalno stanje pravoslavnog stanovništva u Kolašinskom srezu, izazvano pljačkom i ubistvima koje su vršili komunisti. Narod je bio u takvoj situaciji "da skoro umire od gladi“, pa je molio italijansku pomoć, pogotovo u hrani. ${ }^{40}$

Već 13. marta Đurišić i Simoneli su imali novi sastanak. Razgovorom je i ovoga puta dominirao vojni faktor. Đurišić je italijansku stranu upoznao sa načinom borbe protiv glavnine partizanskih snaga razmeštenih na Kamenoj gori, Šahovićima, Kovrenu i dalje, širom Pljevaljskog sreza, sve do Foče. Smatrao je da će im se najlakše suprotstaviti ako zadrži Kolašin po svaku cenu. Tog stava će se držati tokom celog rata. Stoga je za odbranu varoši angažovao oko 2.000 ljudi, naredio fortifikaciju grada i sam boravio u njemu. Uspeh svojih namera ponovo je uslovio isporukom veće količine oružja sa kojim bi „za mesec dana, ili čak i manje, uništio potpuno komuniste “ ${ }^{41}$ Budući događaji će potvrditi njegove garancije date italijanskom okupatoru.

Krajem marta 1942, posle šest sastanaka, uobličeni su uslovi ugovora o saradnji između italijanskih okupacionih vlasti u Crnoj Gori i kapetana Pavla Đurišića. Oni su izneti njegovom bratu Vasu Đurišiću dok je boravio u Podgorici. Po sadržaju ugovor je bio sličan onom koji je nešto ranije postigao Baja Stanišić, komandant crnogorskih nacionalista iz Podgorice i doline Zete. ${ }^{42}$ Bio je to još jedan korak u izgradnji kolaboracije crnogorskih

${ }^{38}$ Isto, 98; К. Николић, н. g., 480-481.

39 AUSSME, 19. divisione fanteria „Venezia“, bus. N-6/1006, Comando della divisione di fanteria da montagna „Venezia“, Capitano Pavle Giurisic, Nr. 1182, 10. 3. 1942, 1.

${ }^{40}$ Ibid., 1-2.

${ }^{41}$ AUSSME, 19. divisione fanteria „Venezia“, bus. N-6/1006, Comando della divisione di fanteria da montagna „Venezia“, Incontro con Giurisic (6), allegato 19 al diaro storico, 13. 3. 1942, 1-2.

${ }^{42}$ К. Николић, н. g., 480-481. Jedina bitnija razlika je bila u tome što se Đurišić obavezao da vrati artiljeriju i ostalo teško naoružanje Italijanima kada završi sa akcijom protiv partizana, na osnovu čega se može zaključiti da je dobio više oružja od Stanišića. VA, ČA, kut. 134, fasc. 3, dok. 5, 1. 
četnika, koja će biti zaokružena sporazumom Borili-Đukanović 24. jula 1942. Oni će tako postati stub okupacione uprave na teritoriji Guvernatorata Crne Gore. ${ }^{43}$

Komanda trupa Crne Gore tražila je od Đurišića da se obaveže na poštovanje sledećih uslova: 1) da vodi borbu protiv komunista i njihovih pristalica; 2) da održava stalan kontakt sa italijanskim vojnim vlastima i vrši akcije prema njihovim direktivama, tako što bi severno od Lijeve Rijeke bio potčinjen generalu Boniniju, a za teritoriju južno od nje, generalu Mentastiju u Podgorici; 3) da održi red i mir u svojoj zoni i obezbedi sigurnost puteva; 4) da nikada ne okrene oružje protiv italijanskih trupa; 5) da posle sloma komunizma vrati svo oružje osim pušaka, koje će zadržati radi održavanja reda. Italijanska komanda se obavezala na snabdevanje Đurišićevog ljudstva oružjem, novcem i životnim namirnicama. ${ }^{44}$

Ovi uslovi su predstavljeni četničkom komandantu 28. marta 1942. u komandi divizije „Venecija“ u Beranama. Đurišić je izrazio neslaganje sa drugom tačkom, koja ga je obavezivala na praćenje italijanskih direktiva tokom operacija. Sloboda akcije bila je njegova prva želja sa sastanka održanog 3. januara, ali i ona za koju je general Bonini smatrao da mu se ne sme ispuniti. Đurišić se žalio na to da će mu biti teško da, kada odmakne od Berana ili Podgorice, uspostavi i održava komunikaciju sa italijanskom komandom radi primanja naređenja. Italijanska strana je nejasno odgovorila da se "radi o uputstvima ne detaljnim naredenjima“, odnosno da su to "uputstva koja će on povremeno primati i kao komandant crnogorske nacionalističke formacije primenjivati kako smatra da je najbolje“. Time su okupatorske vlasti pokazale da ne žele diskusiju o promeni uslova saradnje. Dogovoreno je da Đurišić pošalje oficire i poverenike u sedište divizije „Venecija“ u Beranama, odnosno u Podgoricu, sa zadatkom održavanja veze. Potom su potpukovnik Amadeo Simoneli i kapetan Pavle Đurišić potpisali akt o vojnoj saradnji. Na dokument su kao svedoci parafe stavili gradonačelnik Berana Vlado Vujošević, predsednik opštine Zaton Milan Bandović i Vaso Đurišić. ${ }^{45}$

U nastavku sastanka postavljeno je pitanje operativne koordinacije između nacionalista i italijanskih trupa. Đurišić je odbacio taj predlog,

${ }^{43}$ Zbornik dokumenata i podataka o Narodnooslobodilačkom ratu jugoslovenskih naroda, tom III, knj. 4 (Beograd: Vojno-istorijski institut Jugoslovenske armije, 1950), 527-530; D. S. Nenezić, $n$.d., 98.

${ }^{44}$ AUSSME, 19. divisione fanteria „Venezia“, bus. N-6/1006, Comando della divisione di fanteria da montagna „Venezia“, Accordi fra il Comando superiore delle Truppe Italiane nel Montenegro ed il capitano Giurisic, 1; Dokumenti o izdajstvu Draže Mihailovića, knj. 1 (Beograd: Državna komisija za utvrđivanje zločina okupatora i njihovih pomagača, 1945), 40.

${ }^{45}$ AUSSME, 19. divisione fanteria „Venezia“, bus. N-6/1006, Comando della divisione di fanteria da montagna „Venezia“, $7^{\circ}$ incontro con il capitano Pavle Giurisic, Allegato nr. 32 al diaro storico, 28. 3. 1942,1. 
prepoznavši u njemu opasnost ograničavanja četničkih akcija i u toku samih borbi sa partizanima. Drugi razlog video je u tome što narod neće odobriti ubijanje Srba u društvu sa Italijanima. Izjavio je da mu zahvaljujući oružju dobijenom od italijanskih vlasti dodatna snaga nije potrebna, te da je već počeo mobilizaciju ljudi za širenje pokreta. Kada mu je naloženo da oružjem koje će dobiti opskrbi i jedinice antikomunističke milicije sa teritorije divizije „Venecija“, nad kojima je trenutno imao komandu ali koje nisu bile deo njegovih trupa, četnički oficir se ponovo usprotivio. Žalio se da Lašićeva grupa ne funkcioniše i da postoje lica u odredu iz Berana koja mu ne odgovaraju. Stoga je izjavio da već regrutuje nove poverljive ljude o kojima će naknadno obavestiti generala Boninija, posle čega je razgovor bio završen. Budući da nisu imali nameru da staju između zavađenih nacionalističkih komandanata, a pogotovo između četnika i partizana, Italijani su bez veće diskusije prihvatili Đurišićeve izgovore. Zatim mu je dozvoljeno da svoju komandu i centar pokreta smesti u Kolašin. ${ }^{46}$

Poslednji u nizu sastanaka tokom kojih je iskovano savezništvo između Đurišića i Italijana održan je 31. marta. Simoneli i Đurišić su diskutovali o isporuci obećanog oružja. Đurišić je insistirao da mu se preda celokupna količina naoružanja ugovorena tokom boravka njegovog brata $\mathrm{u}$ Podgorici, pre početka akcije protiv partizana. Zahtevao je preko toga još 5.000 bombi i 30 mitraljeza tipa „Breda M37“. Pošto je planirao da pod komandom ima 3.600 ljudi, interesovao se da li će Italijani imati dovoljno namirnica za njihovo snabdevanje, na šta je dobio potvrdan odgovor. ${ }^{47}$

Osetivši da je trenutak povoljan, Đurišić se osvrnuo i na rad muslimanskog prvaka iz Petnjice Osmana Rastodera. Preneo je Simoneliju da je tih dana imao sastanak sa njim, ali da je Rastoder odbio bilo kakav dogovor, na osnovu čega je oficir JVuO zaključio da muslimani iz ovog kraja „ne žele ni mir ni red od pravoslavaca već borbu“, te da su na stanovištu „da samo puška može da reši ta neslaganja". Dodao je da Rastoder radi na tome da se granica Velike Albanije proširi sve do Lima, te da mu je na sastanku odbrusio kako više nije pod nadležnošću „Venecije“ već Tirane. Na kraju, Đurišić je izjavio da „njegova želja nije da stvara trvenja sa muslimanima, kako ne bi to preraslo u sukobe". Upozorio je Italijane da će po odlasku u Bjelopoljski srez radi akcije protiv komunista ostaviti manje snage po selima na desnoj obali Lima, te da mu ne bi bilo drago ako bi ove trupe „bile primorane da se bore sa muslimanima". Ponudio se stoga da posredstvom Italijana "obnovi dogovor (sa muslimanima, potpisan februara u Bijelom Polju - M. Ž.) i da ne dela

${ }^{46}$ Ibid., 1-2.

${ }^{47}$ AUSSME, 19. divisione fanteria „Venezia“, bus. N-6/1006, Comando della divisione di fanteria da montagna „Venezia“, $8^{\circ}$ incontro con il capitano Pavle Giurisic, Allegato nr. 32 al diaro storico, 28. 3. 1942, 1. 
nasiljem“, obećavši sa svoje strane „tolerantan odnos" da sukobi ne bi eskalirali. Simoneli je garantovao Đurišiću da će pravoslavno stanovništvo biti zaštićeno i da na tome radi lično komandant divizije Bonini. ${ }^{48}$

Đurišić nije bio ubeđen da su italijanske vlasti spremne da mu pomognu, pa je nastavio razgovor o ovoj temi. Žalio se da komunisti šire propagandu protiv njegovog pokreta među muslimanskim življem pričom da će se on uskoro okrenuti protiv njih i povesti borbu „do potpunog uništenja muslimana“. Po Đurišiću, stvarnost je bila drugačija, jer muslimani iz Bihora „često pljačkaju i napadaju“, pa su tih dana ubili nekoliko žena koje su, po njima, nedozvoljeno prešle albansku granicu. Ako Turska uđe u rat protiv Trećeg rajha i njegovih saveznika, muslimanski elemenat u ovim krajevima okrenuće se protiv Italijana, upozorio je Đurišić. ${ }^{49}$

Vršilac dužnosti komandanta divizije „Venecija“, pukovnik Alberto Barasi (Alberto Barassi), naredio je da se 1. aprila Đurišiću preda prva tranša oružja: 964 puške, 99.000 komada municije za puške, 20 teških mitraljeza, 80.000 komada municije za iste, 20 minobacača kalibra 81 milimetar sa 1.000 granata i 2 brdska topa kalibra 65 milimetara. Problem je nastao oko broja artiljerijskih i automatskih oružja. Vaso Đurišić je uveravao svog brata da su mu obećana 4 topa i 50 teških mitraljeza. Posle žalbe kapetana Đurišića, poslat mu je još jedan top i 30 teških mitraljeza. Što se tiče snabdevanja, Đurišić je tražio da se novac za četnike uplaćuje preko njegovog poverljivog čoveka koji će na svakih 15 dana dolaziti u komandu divizije $u$ Beranama. Namirnice za ljudstvo je trebalo slati na 10 dana, svaki put oko jedne tone, uključujući i hranu. Dogovoreno je da se $u$ Beranama uskladišti količina namirnica za jedan mesec, radi sprečavanja zastoja u snabdevanju. Time je stavljena tačka na dogovor. ${ }^{50}$

Kapetan Đurišić je, dakle, na prvim sastancima januara 1942. uspeo da se prikaže italijanskoj strani kao potencijalni saveznik, iako je ona pokazivala izvesne rezerve. Njegov početni uspeh bio je u tome što ga italijanska vojska nije napadala. Taktičkim pristupom daljem toku pregovora (čiji je početak i nastavak inicirao), to jest stalnim zalaganjem za zaštitu okupator-

${ }^{48}$ Ibid. Ratoboran stav muslimana sa desne obale Lima i pograničnih prefektura Rožaje i Tutin imao je podršku guvernera Albanije Frančeska Đakomonija (Francesko Jakomoni). On je podsticao njihove napade na pravoslavni živalj i zahteve za proširenje granice Velike Albanije, nadajući se da će tako destabilizovati Guvernatorat Crnu Goru, samim tim i svog glavnog političkog suparnika na južnom Balkanu, generala Birolija. Dž. H. Bergvin, n. d., 140.

${ }^{49}$ AUSSME, 19. divisionefanteria „Venezia“, bus. N-6/1006, Comando della divisione di fanteria da montagna „Venezia“, $8^{\circ}$ incontro con il capitano Pavle Giurisic, Allegato nr. 32 al diaro storico, 28. 3. 1942, 2.

${ }^{50}$ AUSSME, 19. divisione fanteria „Venezia“, bus. N-6/1006, Comando della divisione di fanteria da montagna „Venezia“, $7^{\circ}$ incontro con il capitano Pavle Giurisic, Allegato nr. 35 al diaro storico, 31. 3. 1942, 1. 
skih interesa u Crnoj Gori kao i uspešnom akcijom na suzbijanju komunista u Beranskom, Bjelopoljskom i Kolašinskom srezu, Đurišić je uspeo da diviziju „Venecija“ pretvori u saveznika. Na ruku mu je išao i pozitivan stav italijanske vrhovne vojne komande o pitanju saradnje sa četnicima, tako da su okupatorske vlasti prešle preko očiglednih podataka o njegovoj saradnji sa generalom Mihailovićem. Promena italijanskog stava prema Đurišiću može se sagledati kroz karakteristike koje je o njemu pisao general Bonini u januaru i februaru 1942. Paralelno sa time povećavane su isporuke oružja i municije za Đurišićeve četnike. One su se od simbolične količine dobijene tokom januara, povećale u februaru, da bi posle sporazuma krajem marta prerasle $u$ nekoliko stotina pušaka, na desetine komada automatskog oružja i čak artiljerije, uz veću količinu municije, hrane i novca. Ova pomoć omogućila je Đurišiću da učvrsti i poveća svoje jedinice, koje su nadmašile komunističke snage i potisle ih iz Crne Gore i Starog Rasa. Italijani su mu, takođe, čuvali zaleđe od eventualnih muslimanskih akcija na desnoj obali Lima. Sporazumnim vezivanjem Đurišića i njegovih četnika italijanske vlasti su dodatno učvrstile okupacione pozicije i rešile problem partizanske gerile u većem delu Crne Gore, pripremajući teren za institucionalno utemeljenje kolaboracionističkih snaga. S druge strane, Đurišićevu neophodnost u borbi sa komunistima pokušale su da umanje i ograniče određenim tačkama ugovora. One su predviđale da njegove operacije protiv partizana moraju biti odobrene i kontrolisane od strane komande divizije „Venecija“ ili Komande trupa Crne Gore, odnosno obuhvatale su vraćanje dobijene količine oružja, izuzev pušaka.

\section{IZVORI I LITERATURA}

- Archivio dell'Ufficio storico dello Stato maggiore dell'Esercito (AUSSME), 19. divisione fanteria „Venezia“, busta N-5/811

- Vojni arhiv Srbije (VA), Četnička arhiva (ČA)

- Arhiv Jugoslavije (AJ), fond 110, Državna komisija za utvrđivanje zločina okupatora i njihovih pomagača (DKRZ)

- Dokumenti o izdajstvu Draže Mihailovića, knj. 1. Beograd: Državna komisija za utvrđivanje zločina okupatora i njihovih pomagača, 1945.

- Zbornik dokumenata i podataka o Narodnooslobodilačkom ratu jugoslovenskih naroda, tom III, knj. 4. Beograd: Vojno-istorijski institut Jugoslovenske armije, 1950.

- Glas Crnogoraca (1942)

- Bolletino dell'Archivio dell'Ufficio Storico, anno II, numero 3-4, Roma: Ufficio Storico Stato maggiore dell'Esercito, 2002. 
- Bergvin, Džejms. Imperija na Jadranu. Musolinijevo osvajanje Jugoslavije 1941-1943. Beograd: Službeni glasnik, 2007.

- Muratović, Zumber. Sandžački gazija Osman Rastoder. Sarajevo: Zumber Muratović, 2002.

- Nenezić, Dragan. Jugoslovenske oblasti pod Italijom 1941-1943. Beograd: Vojno-istorijski institut Vojske Jugoslavije, 1999.

- Николић, Коста. Исйорија равноїорскої йокрейа: 1941-1945, I-II. Београд: Завод за уџбенике, 2014.

- Пајовић, Радоје. Конйрареволуиија у Црној Гори. Чейниики и феgерали-

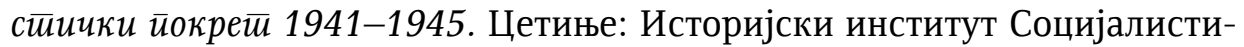
чке републике Црне Горе, 1977.

Milutin Živković

\section{ESTABLISHING OF COOPERATION BETWEEN THE COMMANDER OF LIM-SANDŽAK CHETNIK DETACHMENT PAVLE DJURIŠIĆ AND ITALIAN AUTHORITIES IN MONTENEGRO IN EARLY 1942}

\section{Summary}

At the beginning of 1942, the ideological conflict in Montenegro sharpened due to revolutionary terror of the Communists. Captain Pavle Djurišić saw the solution for this difficult situation in cooperation with the Italian military authorities in Montenegro. Therefore, he started negotiating with them via command of 'Venice' division, stationed in Berane. Initial meetings in January were marked by the distrust of Italians towards Djurišić, first of all owing to his participation in July uprising, relations with General Dragoljub Mihailović and substantial quantity of weapons he asked for. The attitude of Italian occupier towards the military cooperation with him changed during the second half of January, particularly thanks to the success he achieved in the fight with the Communist forces In February 1942 and confidential information he provided from the field. The military cooperation was established at the end of March by signing the five point contract, followed by providing Djurišić with weapons, ammunition, military material and food he had asked for at the beginning of January. Italian help, not only in weapons, but also in logistics enabled the officers of Yugoslav Homeland Army to strengthen and consolidate their troops and take advantage over the Communists in the conflict. 
KEYWORDS: Captain Pavle Djurišić, appointment, General Bonini, Lieutenant Colonel Simonelli, Division „Venezia“, Montenegro Command of the Italian Army

\section{COOPERAZIONE CHE ISTITUISCE COMANDANTE LIM-SANGIACCATO CHETNIK DISTACCO PAVLE DJURIŠIĆ E AUTORITÀ ITALIANE IN MONTENEGRO ALL'INIZIO DEL 1942}

\section{Sommario}

Nel inizio del 1942 il conflitto ideologico in Montenegro è diventato più duro per il terrore revoluzionario dei comunisti. Via d'uscita da una situazione difficile in cui si è trovato, per il capitano Pavle Djurišić era la collaborazione con le autorità militari italiane in Montenegro. Perciò, tramite il comando della divisione "Venezia“ con la sede a Berane, ha aperto le trattative con loro. I primi contatti in gennaio erano caratterizzati da una sfiducia da parte degli italiani verso Djurišić, per la sua partecipazione nella Luglio rivolta del 1941, per i collegamenti con generale Dragoljub Mihailović, e perché ha richiesto una grande quantità delle armi. L'atteggiamento dell'occupatore italiano, per quanto riguarda la collaborazione militare con lui, è cambiato durante la seconda parte di gennaio, cioè durante il febbraio del 1942, grazie agli successi di Djurišić nei combattimenti contro le forze comuniste e anche grazie alle informazioni confidenziali che gli portava dal campo. La collaborazione militare era definita al fine del marzo con la firma del contratto in cinque punti, dopo di che Djurišić ha ricevuto delle armi, delle munizioni, del materiale militare e del cibo che ha richiesto all'inizio di gennaio. L'aiuto italiano sia nella forma delle armi che nel campo della logistica, era possibile grazie agli ufficiali dell'Esercito jugoslavo in patria che intendeva rafforzare e consolidare le proprie truppe e prevalere nel conflitto contro i comunisti.

PAROLE CHIAVE: capitano Pavle Djurišić, appuntamento, generale Bonini, tenente colonello Simonelli, divisione „Venezia“, Comando Truppe Montenegro 